\title{
Mitochondrial Carrier Homolog 2
}

National Cancer Institute

\section{Source}

National Cancer Institute. Mitochondrial Carrier Homolog 2. NCI Thesaurus. Code C102900.

Mitochondrial carrier homolog 2 (303 aa, $33 \mathrm{kDa}$ ) is encoded by the human MTCH2 gene. This protein is involved in the modulation of mitochondrial polarization. 